\title{
ОСОБЛИВОСТІ СТРУКТУРНОЇ ОРГАНІЗАЦІЇ ГЕМОМІКРОЦИРКУЛЯТОРНОГО РУСЛА ЖУВАЛЬНОГО М'ЯЗА ЩУРА
}

\begin{abstract}
Резюме. Жувальний м'яз постійно та інтенсивно працює, тому він має щільну васкуляризацію, а кровопостачання його належить до регіонарного кровотоку. Як відомо, при різних патологічних станах і захворюваннях власне порушення кровотоку в гемомікроциркуляторному руслі (ГМЦР) призводить до розвитку міопатій різного генезу.

Мета дослідження - встановити особливості будови ГМЦР жувального м'яза щура в нормі.

Матеріали і методи. Матеріалом для дослідження послугували жувальні м'язи 10 статевозрілих щурів-самців лінії Вістар масою тіла 180-200 г. Використали гістологічний (забарвлення гематоксиліном та еозином і за Хартом), гістохімічний (імпрегнація Більшовського-Грос) та електронно-мікроскопічний методи дослідження. Комп'ютерне опрацювання даних проводили за допомогою статистичного пакета Stat.Soft.Inc; Tulsa, OK, USA; Statistica 6.

Результати досліджень та їх обговорення. Кровоносні судини в жувальному м'язі деревоподібно поділяються. Дрібні артерії йдуть паралельно до м'язових волокон і дають початок артеріолам, які проходять косо або під прямим кутом до поздовжньої вісі цих волокон. Від артеріол відходять метаартеріоли, від яких беруть початок капіляри. Останні розташовані паралельно до м'язових волокон і широко анастомозують між собою. Особливістю будови соматичних гемокапілярів $є$ наявність в їхній стінці світлих і темних ендотеліоцитів. Мікросудини, які беруть участь у кровопостачанні нейром'язових закінчень (НМЗ) жувального м'яза, беруть початок від внутрішньом'язового ГМЦР. Метаартеріоли фрормують при дихо- або трихотомічному поділі сітку гемокапілярів, яка складається з відкритих і закритих петель різної форми (прості, вилко- і петлеподібні). Як показали наші дослідження, в ділянці НМЗ немає артеріоло-венулярних анастомозів і вся кров перфузується через гемокапіляри, що очевидно пов'язано з необхідністю постійного кровопостачання для забезпечення високого рівня метаболізму в НМз. Разом 3 тим, діаметр гемокапілярів в ділянці кінцевих рухових пластинок на 10-20 \% менший від діаметра просвіту кровоносних гемокапілярів, які забезпечують живленням м'язові волокна.

Висновки. Звужений просвіт гемокапілярів НМЗ, із точки зору гемодинамічних умов, забезпечує відносно низьку швидкість кровотоку, сприяє більш повній віддачі еритроцитами кисню і поживних речовин, до дефіциту яких дуже чутливі
\end{abstract} HM3.

Ключові слова: жувальний м'яз; нейром'язове з'єднання; гемомікроциркуляторне русло.

вСтУп Жувальні м'язи забезпечують механічну обробку їжі. Від сили їхнього скорочення залежить величина жувального тиску, необхідного для відкушування і розмелювання їжі до потрібної консистенції. Також жувальні м'язи беруть участь у мовленні й ковтанні [1]. Власне жувальний м'яз - найсильніший щодо створювання зусиль м'яз в організмі людини: на корінних зубах він розвиває зусилля до 72 кг [3]. За рахунок того, що цей м'яз інтенсивно працює, то він має щільну васкуляризацію, а кровопостачання його відноситься до регіонарного кровотоку [6].

Як відомо, при різних патологічних станах і захворюваннях власне порушення кровотоку в гемомікроциркуляторному руслі (ГМЦР) призводить до розвитку міопатій різного генезу.

Метою дослідження було встановити особливості будови гемомікроциркуляторного русла жувального м'яза щура в нормі.

МАТЕРІАЛИ I МЕТОДИ Матеріалом для дослідження послугували жувальні м'язи 10 статевозрілих щурів-самців лінії Вістар масою тіла 180-200 г. Експерименти на тваринах проведено відповідно до положення Європейської конвенції про захист хребетних тварин, що використовуються для дослідних та інших наукових цілей (Страсбург, 1986), Директиви Ради Європи 86/609/ЄЕС (1986), Закону України "Про захист тварин від жорстокого поводження" від 15 грудня 2009 року та наказів МОЗ України № 690 від 23.09.2009 р., № 616 від 03.08.2012 р.

Для виявлення нейром'язових з'єднань жувальні м'язи сріксували впродовж 25-30 діб у 12 \% нейтральному фрормаліні. Матеріал промивали і в кріостаті виготовляли зрізи товщиною 30-40 мкм, які обробляли за методом Більшовського-Грос. Для кращого контрастування нервових тер- міналей зрізи занурені у 20 \% розчин азотнокислого срібла поміщали у термостат $\left(\mathrm{t}=37^{\circ} \mathrm{C}\right)$ на $1,5-2,0$ год.

Використали гістологічний (забарвлення гематоксиліном та еозином і за Хартом) та електронно-мікроскопічний методи дослідження. Для електронно-мікроскопічного дослідження шматочки матеріалу фріксували у 2 \% розчині чотириокису осмію, проводили та контрастували за загальноприйнятим методом. Вивчення матеріалу проводили на електронному мікроскопі ПЭМ-125 К при прискорювальній напрузі 75 кВ з наступним фотографруванням при збільшеннях від 1200 до 12000 разів. Напівтонкі зрізи товщиною 1 мкм фрарбували 1 \% розчином метиленової синьки.

Гістологічні препарати і напівтонкі зрізи вивчали під світловим мікроскопом МС 300 (TXР) та фоотографували за допомогою цифрової CCD-камери (Industrial digital camera UHCCD05100KPA-U-NA-N-C-SQ-NA). Mopфoмeтрію здійснювали на вказаних препаратах за допомогою програмного ImageJ v. 1.47 (NIH, USA, http://imagej.nih. gov/ij) NIH USA “Image J" в ручному режимі з урахуванням збільшень. Комп'ютерне опрацювання даних проводили за допомогою статистичного пакета Stat.Soft.Inc; Tulsa, OK, USA; Statistica 6.

РЕЗУЛЬТАТИ ДОСЛІДЖЕНЬ ТА ЇХ ОБГОВОРЕННЯ Кровоносні судини в жувальному м'язі деревоподібно поділяються. Дрібні артерії йдуть паралельно до м'язових волокон і дають початок артеріолам, які проходять косо або під прямим кутом до поздовжньої осі цих волокон. Артеріоли мають такі кількісні характеристики: їхня площа становить $(333,86 \pm 61,91)$ мкм $^{2}$, площа просвіту $(60,52 \pm 9,06)$ мкм $^{2}$, площа стінки - $(273,34 \pm 58,54)$ мкм² $^{2}$. Від артеріол відходять метаартеріоли, від яких беруть початок капіляри. Останні розташовані паралельно до 
м'язових волокон і широко анастомозують між собою. їхня площа складає $(17,78 \pm 2,84)$ мкм² $^{2}$ площа їхнього просвіту - $(6,92 \pm 1,55)$ мкм² $^{2}$ площа стінки - $(10,86 \pm 1,55)$ мкм² $^{2}$. Йовірно, що на кожне волокно припадає декілька капілярів. На таку ж організацію ГМЦР у людини вказує Н. К. Логінова і співавт. [6]. При цьому, за даними ії досліджень, у суміжних мікросудинах кров, як правило, тече в одному напрямку.

Гемокапіляри жувального м'яза за своєю будовою $є$ соматичного типу. Особливістю їхньої будови є наявність у їхній стінці світлих і темних ендотеліоцитів (рис. 1). Ядра ендотеліоцитів, як правило, округлої чи овальної форми 3 незначною кількістю інвагінацій. Каріоплазма представлена еухроматином. Цитоплазма ендотеліоцитів містить цистерни комплексу Гольджі й гранулярної ендоплазматичної сітки, значну кількість вільних рибосом та полісом. У периферичній зоні зустрічаються поодинокі лізосоми і мікрофріламенти. Люменальна та базальна поверхня ендотеліоцитів містить помірну кількість піноцитозних пухирців. Між контактними поверхнями ендотеліоцитів, незалежно від форми мікрогемосудин, зберігається міжклітинна щілина, яка місцями переривається десмосомами і нексусами.

Ззовні до неперервного ендотеліального пласту прилягає базальна мембрана, яка має тришарову структуру помірної електронної щільності. Мітохондрії невеликого розміру з щільним матриксом і розташовані переважно в біляядерній зоні.

Мікросудини, які беруть участь у кровопостачанні нейром'язових закінчень (НМ3) жувального м'яза, починаються від внутрішньом'язового ГМЦР. Метаартеріоли, які супроводжують нервові пучки в ділянці претермінальних відділів НМ3, мають діаметр $(16,2 \pm 2,54)$ мкм і формують при дихо- або трихотомічному поділі сітку гемокапілярів $(d=(5,22 \pm 0,74)$ мкм $)$, що складається з відкритих і закритих петель різної фрорми (прості, вилко- і петлеподібні).

Гетерогенність їхньої геометрії на рівні НМЗ вказує на те, що для жувального м'яза характерні багаточисельні мікросудинні містки, які забезпечують їхню трофріку. Щільність гемокапілярів на 1 мм² $^{2}$ 'язової тканини складає $983,3 \pm 72,65$, а на одне МВ в середньому припадає $(4,8 \pm 0,82)$ мікрогемосудин. При цьому на віддалі $20-25,0$

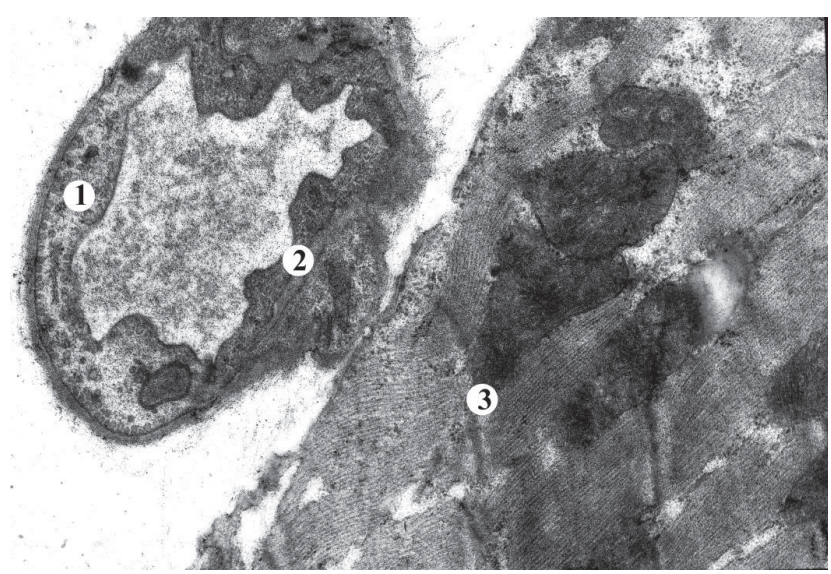

Рис. 1. Ультраструктура гемокапіляра жувального м'яза щура в нормі. Електронограма. 3б. 12000.

Примітка. 1 - світлий ендотеліоцит, 2 - темний ендотеліоцит, 3- м'язове волокно. мкм від НМЗ лежать декілька аркад гемокапілярів (I = 70,0-90,0 мкм). За даними окремих авторів [2], їхня величина знаходиться у прямій залежності від площі нервових закінчень. При цьому навколо великих за площею НМ3 (більше 385,0 мкм²) площа ГМЦР на 52,1 \% більша, ніж навколо малих (менше 300,0 мкм²). Дані дослідження стосуються НМЗ м'язів язика.

Від злиття гемокапілярів формуються закапілярні судини (d=(16,22 $\pm 1,23)$ мкм), кров із яких поступає у венули $(\mathrm{d}=(26,42 \pm 1,32)$ мкм). Венули характеризуються наступними кількісними ознаками: площа судини $(389,42 \pm 55,07)$ мкм $^{2}$, площа просвіту - $(154,61 \pm 36,10)$ мкм² $^{2}$ площа стінки - $(234,82 \pm 34,26)$ мкм² $^{2}$.

У цілому в структурі жувального м'яза багатоланкові судинні комплекси закономірно повторюються за ходом м'язових волокон, що створює впорядковану багаторазово повторювану тримірну модульну конструкцію ГМЦР. Така ж конструкція, за даними інших авторів, характерна і для скелетних м'язів $[2,7,8]$.

При електронно-мікроскопічному дослідженні виявлено ультраструктурні особливості будови стінки гемокапілярів (рис. 2). Так, у розщепленнях базальної мембрани розташовуються тіла і відростки перицитів. Слід відмітити, що нерідко кровоносні капіляри тісно прилягають до цитолеми кінцевих гліоцитів у ділянці НМЗ. Відомо, що однією з функцій гліоцитів $€$ транспорт поживних речовин [10-12], тому вони є проміжною ланкою між гемокапілярами й аксонними терміналями, які утворюють пресинаптичний полюс НМ3 $[9,10]$. Таким чином, у ділянках НМ3 спостерігається гісто-гематичний бар'єр.

У результаті наших досліджень в ділянці НМЗ вдалось виявити розвинену мікроциркуляторну сітку кровоносних судин модульного типу, яка є похідною гемомікроциркуляторного русла нервів відповідних жувальних м'язів. Така ангіоархітектоніка тісно пов'язана з будовою рухового нервового апарату жувальних м'язів і спостерігається у тварин різних видів $[1,4,7,8]$. При цьому мікросудини транспортної частини ГМЦР проходять поряд 3 внутрішньом'язовими пучками МНВ і претермінальними ділянками моторних закінчень, а розгалуження артеріол чітко підлягає узгодженню з характером розгалуження термінального пучка МНВ. Така конструкція термінального ГМЦР у ділянці НМЗ попереджує ішемію і її гіпоксію,

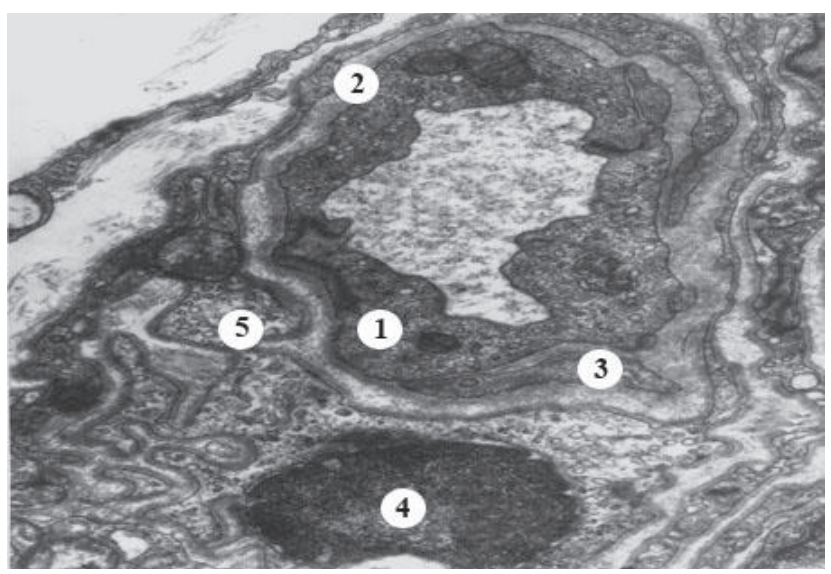

Рис. 2. Ультраструктурна будова гемокапіляра в ділянці нейром'язових закінчень жувального м'яза щура у нормі. Зб. 96000.

Примітки. 1 - ендотеліоцит, 2 - базальна мембрана, 3 - перицит, 4 - ядро нейролемоцита, 5 - пресинаптичний полюс НМ3. 
що її супроводжує, яка може виникати під час надмірного скорочення жувальних м'язів [5].

Відомим фрактом є той, що в модулях ГМЦР жувальних м'язів існує велика кількість артеріоло-венулярних анастомозів, які забезпечують юкстакапілярне кровопостачання [1]. Як показали наші дослідження, в ділянці НМ3 вся кров перфрузується через гемокапіляри, оскільки вищевказаних анастомозів ми не виявили. Таке положення добре узгоджується з даними цілого ряду дослідників [7, 9], які вказують на необхідність постійного кровопостачання для забезпечення високого рівня метаболізму НМЗ у зв'язку з синтезом ацетилхоліну і холінестерази.

Разом з тим, діаметр гемокапілярів у ділянці кінцевих рухових пластинок на 10-20 \% менший від діаметра просвіту кровоносних гемокапілярів, які забезпечують живленням м'язові волокна. На нашу думку, звужений просвіт гемокапілярів НM3, з точки зору гемодинамічних умов, забезпечує відносно низьку швидкість кровотоку, сприяє більш повній віддачі еритроцитами кисню і поживних речовин, до дефіциту яких дуже чутливі НМЗ. Треба відмітити, що в ділянці НМЗ перехід артеріальних мікросудин у венозні відділи відбувається порівняно на короткій відстані. При цьому утворені однією артеріолою гемокапіляри формують дві венули, які на своєму протязі приймають закапілярні судини, по яких відбувається відтік крові від м'язових волокон. Джерела відтоку крові у ділянці НМЗ, які ми встановили, свідчать про те, що вони не мають власного, ізольованого венозного відділу, що створює більш сприятливі умови кровообміну і вищі резерви об'ємної ланки ГМЦР.

\section{СПИСОК ЛІТЕРАТУРИ}

1. Анатомо-фризиологические особенности челюстно-лицевой области и методы ее исследования : учебное пособие / В. В. Белошенков, Н. В. Курякина, М. М. Лапкин, Р. В. Патловская. - М. : Медицинская книга, 2005. - 180 с.

2. Атаманчук О. В. Мікроциркуляторне русло нервово-м'язових веретен власних м'язів язика в нормі / О. В. Атаманчук // Морфологічні аспекти мікроциркуляції в нормі та патології : Всеукраїнська науково-практ. конфр. (Тернопіль, 17-18 червня 2011 р.) : матер. конс. - Тернопіль, 2011. - С. 7-9.

3. Гипертонус жевательных мышц и его коррекция БТА при эстетических проблемах нижней половины лица / М. И. Сойхер, О. Р. Орлова, Л. Р. Мингазова, М. Г. Сойхер // Вестник Эстетической Медицины. - 2011. - Т. 10, № 1. - С. 58-64.

4. Денисенко Ю. П. Современные представления о структурно-фуункциональной организации нервно-мышечной системы и механизмов сокращения и расслабления скелетных мышц / Ю. П. Денисенко, Ю. В. Высочин, Л. Г. Яценко // Педагогикопсихологические и медико-биологические проблемы физической культуры и спорта. - 2011. - Т. 21, № 4. - С. 39-49.

5. Коряк Ю. А. Нейромышечные изменения под влиянием семисуточной механической разгрузки мышечного аппарата у человека / Ю. А. Коряк // Международный журнал прикладных и фрундаментальных исследований. - 2010. - № 10. - С. 10-15.
Має значення величина відстані між гемокапілярами і НМ3, оскільки на цій ділянці відбувається транспорт низькомолекулярних сполук і дифрузія кисню. Кількісний аналіз, який ми провели, показав, що у щурів гемокапіляри розташовані в радіусі 30 мкм від НМЗ. Разом з цим, найбільша їхня кількість розташовується на відстані від 5 до 15 км. У такому ж самому радіусі знаходяться гемокапіляри, які кровопостачають нервові клітини [10]. Тому зону 1-15 мкм можна вважати найбільш оптимальною для забезпечення обмінних процесів між гемокапілярами і структурними компонентами периферійного нервового апарату жувальних м'язів.

ВИСНОВкИ 1. Гемомікроциркуляторне русло жувального м'яза характеризується гетерогенністю, особливо на рівні обмінних мікросудин. Гемокапіляри мають прямолінійний хід, розташовані паралельно вздовж м'язових волокон і з'єднані між собою чисельними містками, фрормуючи у сполучнотканинній основі м'язів широкі петлі у вигляді аркад. Інтима мікросудин характеризується наявністю світлих і темних ендотеліоцитів.

Нейром'язові з'єднання мають спеціалізовані структурно впорядковані ланки гемомікроциркуляторного русла, що утворюють мікросудинні петлі різної фоорми (прості, вилко- і петлеподібні). В ділянці НМЗ наявний гістогематичний бар'єр.

Перспективи подальших досліджень Перспективними є дослідження змін у гемомікроциркуляторному руслі жувальних м'язів та НМЗ при експериментальному цукровому діабеті та їхній вплив на розвиток діабетичної міопатії.

6. Логинова Н. К. Оценка кровоснабжения жевательных мышц при ультразвуковой допплерографии : пособие для врачей / Н. К. Логинова, Е. В. Логацкая, М. Б. Гирина. - М., 2005. - 11 с.

7. Мосендз Т. Гісто-ультраструктура нервово-м'язових закінчень та гемомікроциркуляторного русла скелетних м'язів в нормі і в умовах експериментальної дегідратації / Т. Мосендз // Науковий вісник Ужгородського університету : серія Біологія. 2011. - Вип. 30. - С. 128-132.

8. Попель С. Л. Будова і кровопостачання рухових нервових закінчень скелетних м'язів щурів різного віку / С. Л. Попель, Б. М. Мицкан, Войтик Чорний // Морфологія. - 2012. - Т. 6, № 3. - С. 51-57.

9. Awan Z. A. Synaptic organization of monosynaptic connections from mesencephalic trigeminal nucleus neurons to hypoglossal motoneurons in the rat / Z. A. Awan, T. Wester, K. Kvernebo // Synapse. - 2003. - № 9. - P. 52-59

10. Kreisman N. R. Taurine enhances volume regulation in glial cells swollen osmotically on neuromuscular junction / N. R. Kreisman, J. E. Olson // Neuroscience. - 2003. - Vol. 120, № 3. - P. 635-642.

11. Stan R. V. Endothelial stomatal and fenestral diaphragms in normal vessels and angiogenesis / R. V. Stan // J. Cell Mol. Med. - 2008. - Vol. 12, № 1. - P. 355-360.

12. Zho G. The vessel wall and its interactions / G. Zho, D. D. Wagner, P. S. Frenette // Blood. - 2008. - Vol. 111, № 11. - P. 5271-5281. 


\section{PECULIARITIES OF STRUCTURAL ORGANIZATION OF HEMOMICROCIRCULATORY CHEWING MUSCLE IN RATS}

Summary. The chewing muscle constantly and intensively works, therefore it has a dense vascularization, and its blood supply concerns to a regional blood flow. As known in various pathological conditions and diseases, the actual blood flow disturbance in the hemocirculatory channel (HMCR) leads to the development of various genesis myopathies.

The aim of the study - to establish the structural features of the HMCR of rat chewing muscle in the norm.

Materials and Methods. The material for the study was the masticatory muscles of 10 mature male rats of the Wistar line (body weight 180-200 g). Histological (staining with hematoxylin-eosin and according to Hart), histochemical (Bilshovskyi-Gros impregnation) and electron microscope methods were used. Computer processing of data was carried out using the statistical package Stat.Soft.Inc; Tulsa, OK, USA; Statistica 6.

Results and Discussion. Blood vessels in the chewing muscle are divided into a tree. Small arteries run parallel to the muscle fibers and give rise to arterioles that run obliquely or at right angles to the longitudinal axis of these fibers. A feature of the structure of somatic hemocapillaries is the presence in their wall of light and dark endotheliocytes. Microvessels participating in the blood supply of neuromuscular endings (NME) of the masticatory muscle originate from the intramuscular HMCR. Meta-arterioles form a hemocapillary mesh under breath- or trichotomous separation, which consists of open and closed loops of different shapes (simple, fork and loop). As our studies in the area of NME show, there are no arterio-venular anastomoses and all blood is perfused through hemocapillaries, which is obviously due to the need for permanent blood supply to ensure a high level of metabolism in NME. At the same time, the diameter of hemocapillaries in the region of the terminal motor plates is $10-20 \%$ less than the diameter of the lumen of blood hemocapillaries, which provide muscle fiber supply.

Conclusions. In our opinion, the narrowing of the hemocapillary lumen of the NME, from the point of view of hemodynamic conditions, provides a relatively low rate of blood flow, contributes to a more complete delivery of red blood cells to oxygen and nutrients, to the deficiency of which are very sensitive to NME.

Key words: chewing muscle; neuromuscular junction; hemocirculatory circulation.

(с)А. А. Град

ГВУз “Ивано-Франковский национальный медицинский университет”

\section{ОСОБЕННОСТИ СТРУКТУРНОЙ ОРГАНИЗАЦИИ ГЕМОМИКРОЦИРКУЛЯТОРНОГО РУСЛА ЖЕВАТЕЛЬНОЙ МЫШЦЫ кРЫСЫ}

Резюме. Жевательная мышца постоянно и интенсивно работает, поэтому она имеет плотную васкуляризацию, а кровоснабжение ее относится к регионарному кровотоку. Как известно, при различных патологических состояниях и заболеваниях собственно нарушение кровотока в гемомикроциркуляторном русле (ГМЦР) приводит к развитию миопатии различного генеза.

Цель исследования - установить особенности строения ГМЦР жевательной мышцы крысы в норме.

Материалы и методы. Для исследования послужили жевательные мышцы 10 половозрелых крыс-самцов линии Вистар массой тела 180-200 г. Использовали гистологический (окраска гематоксилином и эозином и по Харту), гистохимический (импрегнация Бильшовского-Грос) и электронно-микроскопический методы исследования. Компьютерные обработки данных проводили с помощью статистического пакета Stat.Soft.Inc; Tulsa, OK, USA; Statistica 6.

Результаты исследований и их обсуждение. Кровеносные сосуды в жевательной мышце древовидно делятся. Мелкие артерии идут параллельно мышечным волокнам и дают начало артериолам, которые проходят косо или под прямым углом к продольной оси этих волокон. От артериол отходят метаартериолы, от которых берут начало капилляры. Последние расположены параллельно мышечным волокнам и широко анастомозируют между собой. Особенностью строения соматических гемокапилляров является наличие в их стенке светлых и темных эндотелиоцитов. Микрососуды, участвующих в кровоснабжении нейромышечных соединений (НMC) жевательной мышцы берут начало от внутримышечного ГМЦР. Метаартериолы формируют при дихо- или трихотомическом разделении сетки гемокапилляров, которая состоит из открытых и закрытых петель разной формы (простые, вилко- и петлеобразное). Как показали наши исследования, в области НМС нет артериоловенулярных анастомозов и вся кровь перфузируется через гемокапилляры, что очевидно связано с необходимостью постоянного кровоснабжения для обеспечения высокого уровня метаболизма в НМС. Вместе с тем, диаметр гемокапилляров в области конечных двигательных пластинок на 10-20 \% меньше диаметра просвета кровеносных гемокапилляров, которые обеспечивают питанием мышечные волокна.

Выводы. По нашему мнению, сужение просвета гемокапилляров НMC, с точки зрения гемодинамических условий, обеспечивает относительно низкую скорость кровотока, способствует более полной отдачи эритроцитами кислорода и питательных веществ, к десициту которых очень чувствительны НМС.

Ключевые слова: жевательная мышца; нейромышечные соединения; гемомикроциркуляторное русло. 